\title{
KONFLIK ETNIS SAMBAS TAHUN 1999 ARAH DISINTEGRASI BANGSA
}

\author{
Oleh: Eka Jaya PU* \\ *Program Studi Pendidikan Sejarah IKIP PGRI Pontianak \\ Email. Ekajpu.ikipptk@gmail.com
}

\begin{abstract}
ABSTRAK
Tulisan ini memaparkan kronologis terjadinya konflit antar etnis di Sambas pada tahun 1999 dan menelaah peran pemerintah serta masyarakat dalam rangka rekonsiliasi konflik. Kajian konseptual yang dimanfaatkan yakni pendekatan sosial, ekonomi dan politik. Secara struktural konflik antar etnis tidak terlepas dari keterlibatan pihak tertentu yang menggunakan simbol-simbol etnis yang hidup di masyarakat. Kalimantan Barat merupakan daerah yang multilkultur dari berbagai macam aspek, dengan rusaknya simbol-simbol tersebut maka gesekan mudah terjadi dan menimbulkan konflik horizontal. Kompetisi dan lapangan pekerjaan yang sempit, penguasaan atau monopoli lahan pertanian hingga pemasaran jeruk Sambas, merupakan awal masalahnya.
\end{abstract}

Kata Kunci: Konflik Etnis Sambas, Disintegrasi Bangsa.

\section{A. PENIDAHULUAN}

Kalimantan Barat adalah daerah yang memiliki masyarakat, budaya, orang-orang heterogen. Selain itu, Kalimantan Barat kaya akan sumber alam yang berguna untuk kesejahteraan masyarakatnya. Seiring perubahan jaman, apalagi di masa globalisasi ini mobilitas masyarakat semakin cepat untuk mendapatkan informasi dari luar sehingga memberikan pengaruh yang luar biasa dalam rangka pembentukan karakter, pemikiran dan wawasan seseorang. Ketika melihat ke belakang, Kalimantan Barat salah satu dareah di Indonesia yang sering terjadi peristiwa kerusuhan antar orangorang. Konflik ini terjadi tidak semata-mata hanya disebabkan oleh faktor ekonomi saja melainkan ada hal lain yang mungkin merupakan sesuatu yang sensitif, misalnya penguasaan tanah, pasar, penggantian peran kelompok lokal oleh kelompok pendatang ataupun tidak mematuhi aturan adat yang berlaku di daerah tersebut.

Kondisi multikulturalitas kebangsaan diibaratkan sebagai pedang bermata ganda; di satu sisi merupakan modalitas yang bisa menghasilkan energi positif tetapi di sisi lain keanekaragaman yang ada apabila tidak dapat dikelola dengan baik maka akan menjadi ledakan destruktif yang dapat menghancurkan struktur dan pilar-pilar kebangsaan atau menuju disintegrasi bangsa (Mahfud, 2009:80). Multikulturalisme adalah konsep yang menjelaskan dua perbedaan dengan makna yang saling berkaitan. Multikulturalisme sebagai kondisi kemajemukan kebudayaan atau pluralisme budaya dari suatu masyarakat (Liliweri, 2005:68). Multikultural tidak akan mengganggu keutuhan negara karena rakyat Indonesia sudah menyadari bahwa kerukunan dalam komunitas lebih menyenangkan dalam kerjasama (Arif, 2011:5). Seringnya terjadi konflik antar orang-orang pada dasarnya mengganggu mobilitas sosial, ekonomi, politik dan bahkan keamanan yang menjadi mahal harganya. Kalimantan Barat mengalami konflik antar orang-orang sejak puluhan tahun lalu, yang secara umum mengalami tujuh kali yang dimulai pada tahun 1952 di Semalantan, 1968 dan 1976 di Sungai Pinyuh, 1977 di Singkawang, 1983 di Sungai Ambawang, 1993 di kota Pontianak, 1996 di Sanggau Ledo dan yang terakhir di Sambas tahun 1999 (Cahyono, 2008:97-98).

Konflik antar orang-orang tidak dapat dilepaskan dari realitas sosial sepanjang sejarah Kalimantan Barat. Konflik sosial berkali-kali terjadi tercatat sudah dimulai 
pada tahun 1950-an, khususnya pertikaian antara orang-orang Madura melawan orangorang Dayak yang hingga kini nyaris tiada berkesudahan. Sementara di pihak lain, suku Melayu yang selama ini tidak pernah terlibat dalam konflik ternyata harus angkat senjata bertikai dengan orang-orang Madura. Konflik ini bersifat murni konflik orang-orang bukan merupakan konflik atas kepentingan agama. Konflik yang terjadi terakhir ini adalah di Sambas yakni antara orang-orang Melayu dengan orang-orang Madura pada tahun 1999.

Menurut asumsi dari berbagai macam versi yang mungkin masih subjektif karena ketika ditanya mengenai konflik di Sambas tahun 1999, berdasarkan pada masingmasing kedua belah pihak maka ada pembenaran dan pembelaan dari masingmasing kelompoknya sehingga berita dan isu yang berkembang masih sulit dipercaya. Konflik yang sudah terlanjur terjadi tentunya sangat memilukan karena banyak sekali memakan korban jiwa dan harta benda dari kedua belah pihak. Namun yang menjadi perhatian adalah sudah terancamnya stabilitas keamanan, rusaknya jalinan sosial yang telah lama dibangun bersama dan mematikan sektor ekonomi masyarakat Sambas dan sekitarnya yang banyak bergerak pada perkebunan, ladang atau sawah dan nelayan.

Konflik yang terjadi di Kalimantan Barat merupakan bahaya laten dan daerah ini salah satu wilayah yang paling rawan konflik antar orang-orang. Kehidupan sosial yang cenderung menghidupkan simbolisasi sebagai identitas masyarakat terkadang menjadi salah satu pemicunya. Secara terbatas dalam kajian ini dibahas secara kronologis terjadinya konflik orang-orang di Sambas pada tahun 1999 dilihat dari faktor struktural dan peran pemerintah serta tokoh masyarakat dalam rangka rekonsiliasi konflik di Sambas. Dengan demikian tujuan kajian ini akan mendeskripsikan secara mendalam peristiwa di Sambas pada tahun 1999.

\section{B. PENYEBAB TERJADINYA KONFLIK ETNIS DI SAMBAS TAHUN 1999 \\ Konflik antar orang-orang di} Kabupaten Sambas sebuah peristiwa di luar dan tidak terduga bahwa baru kali ini orangorang Melayu terlibat secara lansung dalam sebuah konflik terutama dengan orangorang Madura. Selama ini yang terjadi konflik antar orang-orang di Kalimantan Barat, yang sering bertikai adalah orangorang Madura dengan orang-orang Dayak. Dari berbagai macam faktor dan alas an penyebab konflik ini terjadi dapat dianalisa melalui perspektif struktural.

Konflik orang-orang Melayu dengan orang-orang Madura Sambas pada tahun 1999 faktor penyebabnya dapat dilacak mulai tahun 1992. Perselisihan terjadi di daerah pedesaan terutama yang dialami petani jeruk dari orang-orang Melayu melawan perusahaan Bimantara Citra Mandiri (BCM). Perusahaan yang berusaha memonopoli pemasaran jeruk. Masuknya perusahaan BCM ternyata mendapat dukungan dari berbagai pihak salah satunya pemerintah dan aparat yang sengaja dalam monopoli pemasaran jeruk. Mulai sejak itulah masyarakat Sambas terutama dari orang-orang Melayu mengalami krisis ekonomi yang sangat luar biasa.

Pada saat situasi krisis ekonomi, orang-orang Melayu harus terpaksa berhadapan dengan tekanan yang datang dari orang-orang Madura. Orang-orang Madura yang merupakan pendatang dinilai ingin menguasai, mendominasi dengan cara kekerasan. Kedatangan orang-orang Madura ke Kabupaten Sambas dari tahun ke tahun semakin bertambah dan sedikit demi sedikit meminggirkan orang-orang Melayu terutama dalam bidang ekonomi akibat krisis jeruk yang membuat mereka semakin frustasi di tanah kelahirannya sendiri.

Aktivitas orang-orang Madura dan orang-orang Melayu didasari oleh persamaan jenis pekerjaan yakni sebagai 
petani dan memilih bekerja tinggal di daerah pedesaan. Sudagung dalam Haryono dan Budi Winarno (2003:679) mengemukankan penelitian tentang migrasi swakarsa orang Madura ke Kalimantan Barat menunjukan bahwa dari sekitar 400 responden orang Madura terdapat $317(79,5 \%)$ responden tidak sekolah atau buta huruf dan 261 $(65,25 \%)$ responden saat datang ke Kalimantan Barat berstatus bujangan dan $268(67 \%)$ responden bekerja di tempat asal sebagai petani, $191(47,8 \%)$ berasal dari Kabupaten Bangkalan dan 205 (52,2) berasal dari Samapang. Saat di daearah asal mereka sebagian besar memiliki tanah kurang dari 0,05 hektar.

Pekerjaan orang-orang Madura yang datang ke Sambas sebagian besar berasal dan bekerja sebagai petani dan buruh. Akibat pekerjaan yang dimasuki oleh orangorang Madura sama dengan kegiatan ekonomi yang telah digeluti oleh orangorang Melayu ternyata terdapat gejala perebutan sumber daya ekonomi terutama tanah pertanian di daerah pedesaan, kompetisi yang tinggi dalam bidang usaha dan persaingan dalam sektor informal. Munculnya gejala awal dimana orang-orang Melayu mulai tergusur oleh orang-orang Madura. Dengan demikian dalam hubungan antar orang-orang mingran dan pennduduk asli di Sambas terdapat kecenderungan hubungan ekonomi ke arah sub ordination of an indigenous by migran.

Sebagian besar orang-orang Madura datang ke Sambas dengan pola transmigrasi swakarsa mandiri tanpa disponsori oleh pemerintah. Pola ini pada akhirnya menimbulkan masalah besar dalam bidang pertanahan, karena para transmigran asal Madura adalah para petani yang membutuhkan lahan pertanian untuk memulai aktivitas hidupnya. Hubungan ekonomi antar orang-orang Melayu dengan Madura sebagian dari mereka bermula sangat baik. Orang Madura bekerja di kebun orang Melayu sebagai penggarap dengan sistem upah. Namun dalam perkembangannya hubungan tersebut berubah menjadi penggarap yang berusaha menguasai tanah yang digarapnya dan mengusir majikannya. Hal yang serupa juga terjadi yaitu dengan cara ketika orang Madura bekerja dan suatu saat disuruh pergi maka mereka menolak dengan berbagai macam dalih. Dalam banyak kasus yang pada akhirnya orang Melayu menjadi pasrah dan justru tidak terlalu ambil pusing dan terpaksa melepaskan hak kepemilikan tanahnya.

Sampai menjelang timbulnya konflik pada tahun 1999, orang-orang Madura yang pada saat datang tidak mempunyai lahan sedikitpun, menurut data Pemda Tingkat II Kabupaten Sambas berhasil menguasai $6.694,78 \mathrm{Ha}$ lahan pertanian dan perkebunan. Sebagian besar tanah yang dikuasai mereka tidak bersertifikat dan tidak sah status kepemilikannya. Kebanyakan pemiliknya hanya dilengkapi dengan Surat Pernyataan Tanah (SPT) dan atau Surat Keterangan Tanah (SKT). Berikut tabel luas lahan orang-orang Madura per Kecamatan dan Status Haknya:

\begin{tabular}{|c|l|c|l|}
\hline No & Kecamatan & Luas (Ha) & \multicolumn{1}{c|}{ Keterangan } \\
\hline 1 & Selakau & 297,85 & Banyak yang tidak jelas status haknya \\
\hline 2 & Sanggau Ledo & 393,25 & Jelas dan bersertifikat \\
\hline 3 & Sungai Raya & 545,37 & Banyak yang tidak jelas status haknya \\
\hline 4 & Jawai & 888,57 & Tidak jelas status haknya \\
\hline 5 & Teluk Keramat & 658,79 & Banyak yang tidak jelas status haknya \\
\hline 6 & Paloh & 92,29 & Banyak yang tidak jelas status haknya \\
\hline 7 & Sambas & 607,34 & Jelas dan bersertifikat \\
\hline 8 & Pemangkat & 483,34 & Banyak yang tidak jelas status haknya \\
\hline
\end{tabular}




\begin{tabular}{|c|l|r|l|}
\hline 9 & Tujuh Belas & \multicolumn{1}{|c|}{152,11} & Tidak jelas statusnya \\
\hline 10 & Sejangkung & $1.219,41$ & Tidak jelas statusnya \\
\hline 11 & Roban & 7,48 & Jelas dan bersertifikat \\
\hline 12 & Pasiran & 1,58 & Jelas dan bersertifikat \\
\hline 13 & Samalantan & 700,14 & Tidak jelas \\
\hline 14 & Tebas & 647,46 & Jelas dan bersertifikat \\
\hline \multicolumn{2}{|c|}{ Jumlah } & $6.694,78$ & \\
\hline
\end{tabular}

Sumber: BPS Kabupaten Sambas, 1999

Terjadi peralihan hak atas kepemilikan lahan pertanian, selain itu juga terjadi perebutan pada lokasi penambangan batu dan tanah uruk. Dalam perebutan tersebut banyak kasus orang-orang Melayu gagal mempertahankan kepemilikan daerah tambangnya. Sampai menjelang meletusnya kerusuhan tahun 1999 hampir seluruh penambangan baru dan tanah telah dikuasai.

Perselisihan tidak hanya terjadi di daerah pedesaan, ternyata dikawasan hutan yang terletak di perbatasan IndonesiaMalaysia terjadi pergulatan seru antara kelompok penebang kayu dari kelompok Madura melawan kelompok Melayu. Sebelum orang Madura memasuki bisnis perkayuan, bisnis terrsebut telah lama digeluti oleh orang Melayu. Namun seiring berjalannya waktu banyak diantara orang Madura berminat untuk ikut andil dalam bisnis tersebut sehingga terjadi persaingan, karena orang Melayu yang mudah mengalah dengan perebutan lokasi area kayu maka secara tidak langsung hampir sebagian daerah hutan di perbatasan juga dikuasai.

Selain sektor pertanian, yang menjadi faktor munculnya perselisihan yakni perebutan usaha dibidang transportasi. Hal ini menjadi penting, karena bidang jasa transportasi merupakan urat nadi yang menjadi sumber pengidupan yang banyak menghasilkan uang. Wajar ketika awalnya bidang ini dikuasai oleh orang-orang Melayu kemudian akhirnya berpindah dikuasai orang-orang Madura sehingga muncul persaingan tidak sehat dan berdampak pada sebuah gesekan-gesekan (Sudagung, 2001).

Konflik antar etnis di Sambas merupakan tidak adanya ikut campur pemerintah daerah maupun pusat untuk mengatur sistem ekonomi yang jelas sehingga sering terjadi kesalahpahaman, iri dan sebagainya yang pada akhirnya menjadi masalah besar. Sektor-sektor informal juga terjadi kompetisi orang Melayu dengan orang Madura diantaranya adalah calo penumpang di terminal bus dan pelabuhan, tukang ojek, jasa penyeberangan sungai, buruh pelabuhan dan usaha pemecahan batu dan bisnis tanah uruk. Orang-orang Melayu dan Madura memiliki semangat kerja yang tinggi.

Pertanian jeruk merupakan awal tulang punggung ekonomi masyarakat Sambas. Usaha pertanian jeruk ini mulai diusahakan besar-besaran sejak tahun 1978 dan mencapai puncaknya sampai pada tahun 1992-1993. Dari jumlah produk pada tahun 1992 sebanyak 524.361 jiwa atau $68,02 \%$ bertempat tinggal di kecamatan sentra penghasil jeruk yang berada di daerah pesisir pantai utara. Kecamatan Tebas dan Pemangkat sebagai sentra utama penghasil jeruk dihuni sebanyak 163.289 jiwa atau $31,14 \%$ dari total jumlah penduduk dai kecamatan sentra penghasil jeruk atau setara dengan $21,18 \%$ dari total penduduk se-kabupaten Sambas pada waktu itu (Purwana, 2003).

Tahun 1992 merupakan awal diberlakukannya tata niaga jeruk oleh pemerintah. Tata niaga jeruk merupakan bentuk kebijakan yang diperoleh oleh 
Pemerintah Daerah Kalimantan Barat, yang bertujuan untuk mengendalikan mekanisme perdagangan jeruk. Kebijakan tersebut diatur dengan beberapa Surat Keputusan Gubernur KDH Tk.I Kalimantan Barat. Keputusan tersebut bersifat mengikat dan harus diikuti oleh pelaku tata niaga, walaupun tanpa pengaturan sanksi yang jelas bagi para pelanggarnya. Keputusan Gubernur tersebut mulai keluarkan pada tanggal 15 April 1988 dengan Kep. No. 88 tahun 1988 yang mengatur pilot proyek pembinaan petani dan pengumpulan hasil produksi di kecamatan Tebas kabupaten Sambas (Haryono, 2003: 684).

Kebijakan tersebut dikeluarkan di samping untuk mengatur perdagangan jeruk, juga untuk lebih memfungsikan Koprasi Unit Desa (KUD). Dengan demikian sebagai pelaksana teknis dari kebijakan tata niaga jeruk adalah KUD dalam hal ini PUSKUD Kalimantan Barat. Dalam pelaksanaannya sehari-hari PUSKUD bekerjasama dengan PT. HUMPUSS Namun kerjasama tersebut tidak berlangsung lama dikarenakan kendala permodalan dan prasarana. Pada tahun 1991 Pemerintah Daerah Kalimantan Barat dengan Suat Keputusan Gubernur 296 tahun 1991, menunjuk PT. Bimantara Citra Mandiri sebagai koordinator pelaksana tata niaga jeruk.

Sejak masuknya PT. Bimantara Citra Mandiri sangat merugikan petani karena setalah perusahaan berdiri harga jeruk cenderung rendah dibanding sebelum masuknya perusahaan tersebut. Hal ini dipengaruhi oleh pola tata niaga jeruk yang harganya selalu dimainkan oleh perusahaan. Mulai saat itu orang-orang Melayu yang berprofesi sebagau petani jeruk mengalami krisis ekonomi luar biasa. Sementara dibidang lain orang-orang Melayu yang bekerja sebagai perambah hutan, di jasa transportasi, tukang ojek dan sebagainya terjepit juga dengan penguasaan lahan dan sektor informal oleh orang Madura. Sebagai akibat dari situasi tersebut banyak dari kalangan generasi muda dari orang-orang Melayu yang terpakasa meninggalkan daerah Sambas untuk merantau ke Malaysia, Batam dan Kota Pontianak.

Orang-orang Madura merupakan minoritas baik dilihat dari segi jumlah maupun besar kekuasaan yang dimiliki. Namun sebagai dampak keberhasilan ekonomi orang Madura, sebagian dari mereka ada yang mulai terjun ke bidang politik. Dalam hubungannya antara mayoritas dengan minoritas terdapat banyak kasus dominasi minoritas di bidang ekonomi ini ada kecenderungan tidak akan berhenti pada satu sektor saja tetapi dapat meluas ke sektor kehidupan lain. Sebagaimana ditegaskan oleh Rothschild (1981: 117) yaitu bahwa setelah pencapaian dominasi ekonomi, golongan minoritas mempunyai kecenderungan untuk memperluasnya ke pengakuan kultural dan kekuasaan politik.

Syarif Ibrahim Alqadrie melihat kepemimpinan politik juga ikut memicu pertikaian. Pemimpin formal setempat, seperti gubernur maupun bupati dinilai belum mampu mengelola pluralitas etnik sebagai suatu kekuatan untuk memajukan kepentingan bersama. Sebaliknya, perbedaan yang ada diupayakan sedemikian rupa agar tidak rukun, sehingga dengan mudah diadu-domba untuk menimbulkan konflik horizontal. Strategi ini merupakan bagian dari upaya mempertahankan kekuasaan dan memperkuat posisi kepemimpinan (Kompas, 20-12-2000).

Dalam tingkat desa orang Madura sudah mampu menempati posisi sebagai aparat desa mulai dari kepala desa sampai pada kepala dusun. Hal ini terjadi di desa Rambayan A dan desa Sempadian, orangorang Melayu yang sebelumnya mayoritas menjadi minoritas dikarenakan banyak diantara mereka pergi meninggalkan kampungnya untuk mendapatkan kehidupan yang lebih baik. Keberhasilan diberbagai sektor hingga mampu masuk dalam dunia 
politik, hal ini menunjukkan bahwa eksistensi orang-orang Madura sangat berpengaruh ketika itu.

Kronologis terjadinya konflik antar etnis di Sambas pada tahun 1999 diawali dengan tertangkapnya seorang beretnis Madura yang berasal dari Desa Sari Makmur Kecamatan Tebas yang tertangkap tangan hendak mencuri sepeda motor di rumah seorang warga Melayu Parit Setia Kecamatan Jawai. Peristiwa ini terjadi pada 17 Januari 1999, Hasan yang merupakan tersangka pencuri ini kemudian ditangkap dan dipukuli warga sebelum diserahkan ke Polsek Jawai. Selanjutnya tiga orang pemuda Madura dari Desa Sari Makmur mendatangi Polsek Jawai dan oleh polisi yang bersangkutan dilepaskan (Cahyono, 2008: 73).

Kepulangan Hasan yang penuh dengan luka akibat pengeroyokan mengakibat keluarganya marah. Bertepatan dengan hari Idul Fitri, pada 19 Januari 1999 sekitas 300 warga Madura dari Desa Sari Makmur menyerang warga Melayu di Desa Parit Setia. Akibatnya 3 orang meninggal dunia diantaranya 2 orang Melayu dan 1 orang Dayak mu'alaf. Setelah peristiwa tersebut diadakan upaya damai dengan mediator camat Tebas, namun pihak Melayu merasa tidak puas sebab penyerbuan tersebut dianggap di tolerir tanpa hukuman yang berarti.

Oknum yang terlibat langsung dalam penyerangan tersebut yang dianggap sebagai tertuduh (pembunuh) setelah disidik menurut saksi korban ternyata bukan pelaku sesungguhnya dan hingga saat ini pelakunya masih misteri. Pihak Melayu meminta para pelaku seluruhnya ditindak tetapi pelaku yang ditangkap hanya 1 orang yakni anak kepala desa yang mempunyai truk untuk alat menganggut warga Madura ketika dalam penyerangan. Sedangkan dari pihak Melayu ditangkap dan diamankan sebanyak 8 orang kesemuanya mengaku sebagai penganiaya pencuri kendaraan (Mendayun, 1999).
Pada bulan yang sama di Selakau, Samalantan, Sanggau Ledo dan beberapa daerah Kalimantan Barat terjadi aksi pembakaran dan penyerangan ke perkampungan orang Madura sehingga konflik sudah tidak dapat diredakan lagi. Daerah Selakau terjadi tabrak lari di pasar Selakau oleh orang Madura, tersangka lari dan tertangkap oleh masa dan dianiaya sampai meninggal. Masa spontan berkumpul mencapai kurang lebih 1.000 orang dan masa bergerak ke beberapa arah melakukan aksi pembakaran rumah yang sudah ditinggalkan oleh penghuninya (Madura) sore harinya terjadi pembunuhan orang Madura yang baru datang dari laut setelah 4 hari mencari ikan di laut saat orang tersebut hendak menjual ikannya. Selanjutnya pembakaran massal terjadi pula di desa Mentibar sampai di daerah pegunungan Selindung (Mendayun, 1999).

Api yang membakar rumah-rumah warga Madura mulai padam. Asap sisa-sisa rumah yang terbakar tak lagi mengepul. Pasukan keamanan, sejak pertengahan pekan berikutnya, ditemui di titik-titik rawan kerusuhan di wilayah Kabupaten Sambas. Namun, kerusuhan antarsuku yang terjadi di wilayah tersebut menyisakan masalah baru, yakni ribuan pengungsi yang berjejalan di tempat-tempat penampungan (Mandayun, 1999).

Akibatnya secara keseluruhan usai Konflik 1999, data resmi menunjukkan bahwa konflik tersebut menyebabkan 200 korban jiwa (Cahyono, 2008:3) dan pengungsian 58.544 orang Madura dari Kab. Sambas. Sampai saat ini Konflik ini diselesaikan pemerintah dengan cara memindahkan orang-orang Madura dari wilayah Kab. Sambas ke Kotamadya Pontianak dan Kota Singkawang. Kondisi ini menyebabkan orang-orang Madura belum bisa kembali ke daerah asalnya di Sambas. Terjadinya penolakan keras dari warga orang-orang Melayu di Sambas bila warga Madura hendak kembali. Meski tidak resmi terdapat batas wilayah perbatasan yang 
boleh dilewati oleh orang Madura ke Sambas, mereka tidak pernah bisa memasukinya. Ada beberapa pendapat dari warga Sambas tentang wilayah yang boleh dimasuki, yaitu batas wilayah administratif pemerintahan kota Singkawang dengan Kabupaten Sambas. Peristiwa tersebut menggambarkan bahwa kemarahan orangorang Melayu Sambas sudah di luar batas kesabaran. Dampak konflik ini semua aspek kehidupan sempat tersendat karena kecurigaan orang yang ingin masuk ke Sambas terlalu berlebihan sehingga pengusaha dan pedagang takut untuk mengembangkan usahanya di Sambas.

\section{PERAN PEMERINTAH DAN MASYARAKAT DALAM RANGKA REKONSILIASI KONFLIK ETNIS DI SAMBAS}

Konflik antar etnis memiliki sejarah yang panjang di Kalimantan Barat, kerusuhan sosial berkali-kali terjadi, khususnya pertikaian hampir tidak pernah usai antara orang-orang Dayak dengan orang-orang Madura. Sementara orangorang Melayu yang tidak pernah terlibat langsung ternyata menyimpan kebencian yang luar biasa terhadap orang-orang Madura secara subjektif ketika dinilai namun itulah adanya di lapangan apabila melihat perilaku orang-orang Madura yang terlalu keras dan idealis dengan kultur mereka. Konflik entar etnis di Sambas sudah beberapa kali mendapatkan respon dari pemerintah yang dilakoni oleh tokoh-tokoh masyarakat setempat namun hasil perjanjian selalu dilanggar karena ketidak sepahaman dan kurangnya toleransi antar etnis dalam kehidupan sehari-hari.

Peran pemerintah dalam resolusi konflik di Sambas dapat dikatakan relatif kurang dan aktivitas pemerintah pada tahap awal konflik berupa de-eskalasi konflik secara umum belum berhasil. Pemerintah mungkin berusaha mengambil tindakan cepat dalam tahap intervensi kemanusiaan, namun itu pun masih terbatas terpaku pada pengurusan para pengungsi korban konflik berupa upaya-upaya untuk mengelola masalah penempatan pengungsi dan inventarisasi aset-aset milik warga Madura di Sambas.

Peran terakhir ini belakangan didukung oleh terbitnya surat edaran Bupati Sambas untuk mengadakan inventarisasi tanah-tanah warga Madura. Namun masih mengalami kegagalan dan kendala pada kurang lengkapnya sertifikat tanah dan status penguasaan tanah yang tidak jelas sehingga tanah-tanah tersebut sulit untuk diambil kembali oleh orang Madura. Kedatangan pasukan Brimob dan Pasukan Huru Hara $(\mathrm{PHH})$ dari Jawa dan Kalimantan Timur justru membawa kerusuhan semakin separadis dan tidak terkendali. Hal ini dikarenakan tindakan dan perilaku aparat di lapangan menimbulkan interpretasi yang berbeda diantara orang-orang yang bertikai (Cahyono, 2008: 110). Orang-orang Melayu mencurigai $\mathrm{PHH}$ yang berasal dari Jawa, karena Madura juga berasal dari Jawa. Sedangkan dilain pihak tentara membiarkan atau tanpa melakukan pengamanan sehingga orang-orang Melayu dengan leluasa menyerang dan menjarah harta milik orang Madura.

Terlepas dari keterangan tersebut kasus kerusuhan di Sambas dipengaruhi hilangnya wibawa aparat di mata masyarakat. Terkait kasus awal Januari 1999, karena aparat tidak mengambil tindakan tegas terhadap oknum pelaku pencurian di desa Parit Setia yang berdampak pada terjadinya pergesekan antar etnis. Peristiwa Parit Setia pada 19 Januari 1999 yang merupakan luapan dan letupan dari sekian banyak konflik yang terjadi sebelumnya. Ketika konflik meletus, aparat keamanan terlihat kesulitan dalam penguasaan geografis dan komunikasi. Semestinya pihak keamanan secepat mungkin mengidentifikasi dan mengantisipasi kemungkinan meluasnya konflik. Kelemahan ini juga terkait dengan sangat terbatasnya jumlah aparat 
keamanan yang tersedia di lapangan. Pihak Pemerintah Daerah dan Provinsi Kalimantan Barat terkesan menghindari isu tentang resolusi konflik. Bahkan ketika akan dilakukannya dialog, Pemerintah Daerah Sambas tidak berani menjamin resiko apabila Pemerintah Provinsi tidak memberi perlindungan kepada orang-orang Madura yang ingin kembali ke Sambas. Dalam penanganan rekonsiliasi konflik di Sambas antara Pemerintah Daerah Sambas dan Pemerintah Provinsi Kalimantan Barat seakan-akan tidak ada koordinasi terutama penanganan masalah pengungsi.

Pendekatan-pendekatan secara informal secara umum menginginkan bagaimana orang Madura dapat membangun citra positif terlebih dahulu kepada Sambas, sehingga bisa menyakinkan orang-orang Melayu Sambas bahwa kepulangan Madura ke Sambas tidak akan menimbulkan konflik kembali. Beberapa elemen atau kelompok masyarakat konsen terhadap masalah perdamaian di Kalimantan Barat, lantas menekankan mengenai pentingnya dibuatkan program-program perbaikan atau merubah sikap dan karakter budaya asal ketika berkomunikasi dan berinteraksi dengan pribumi melalui sosialisasi budaya yang ditujukan kepada orang Madura terutama yang sering berinteraksi dengan warga pribumi.
Hal ini merupakan sangat penting dan bermakna ketika diwujudkan, mereka sudah menurunkan simbol-simbol arogansinya. Bagi para penganut pendekatan alamiah dianggap merupakan diplomasi budaya yang baik. Pengalaman dan kenyaman orang Melayu yang bepergian ke Pontianak ketika mereka pulang secara tidak langsung akan bercerita kepada sanak saudaranya bahwa orang Madura sudah melayani pribumi dengan ramah. Kesan positif harus terus dijaga baik dari orang-orang Madura, Melayu dan Dayak sehingga prasangka atau steriotip dapat dihilangkan sebagai akibat dari ketidakpercayaan setiap pihak yang pernah bertikai.

Hasil penelitian menunjukan di lapangan bahwa simbol-simbol kekerasan orang Madura di Kalimantan Barat sudah sebagian mulai lunak, diantaranya di kota Pontianak, orang Madura tidak mau lagi membawa celurit sebagai ciri khas senjata mereka, walaupun ada namun hanya sebagian, mereka tidak bersikap reaktif lagi, dan relatif telah coba belajar berinteraksi secara lebih halus dengan etnis lain khususnya Melayu. Peran organisasiorganisasi yang sifatnya etnik-eksklusif sudah dilakukan namun masih belum mampu mencapai rekonsiliasi. Berikut adalah tabel peran dari beberapa elemen masyarakat dan organisasi sebagai mediator untuk resolusi konflik:

\begin{tabular}{|c|c|c|}
\hline Jenis Lembaga & Peran & Output \\
\hline LSM & $\begin{array}{l}\text { - } \text { Mengadakan kegiatan } \\
\text { dialog-dialog. } \\
\text { - Bantuan pangan dan } \\
\text { fisik. } \\
\text { - Bantuan pengadaan air } \\
\text { bersih }\end{array}$ & $\begin{array}{l}\text { - Sebatas dialog belum } \\
\text { ada follow up untuk } \\
\text { mendorong resolusi } \\
\text { konflik. } \\
\text { - Di bentuknya LSM } \\
\text { justru untuk mobilitas } \\
\text { politik. }\end{array}$ \\
\hline Partai Politik & $\begin{array}{l}\text { - Secara sadar enggan } \\
\text { terlibat, } \\
\text { mengurus karena } \\
\text { konflik merupakan isu } \\
\text { yang kontraproduktif } \\
\text { bagi partai }\end{array}$ & - Nihil \\
\hline
\end{tabular}




\begin{tabular}{|l|l|l|l|}
\hline $\begin{array}{l}\text { Ikatan-ikatan orang-orang } \\
\text { esklusif(IKRAM, MABM) }\end{array}$ & $\begin{array}{l}\text { Masing-masing bersifat } \\
\text { eksklusif dan hamper } \\
\text { tidak ada kerjasama }\end{array}$ & $\begin{array}{l}\text { Sukar untuk } \\
\text { mempertemukan antar } \\
\text { identitas. }\end{array}$ \\
\hline $\begin{array}{l}\text { Organisasi Lintas orang- } \\
\text { orang } \begin{array}{r}\text { (Forum } \\
\text { Komunikasi Masyarakat } \\
\text { Kalbar) }\end{array}\end{array}$ & $\begin{array}{l}\text { Praktis tidak memiliki } \\
\text { program }\end{array}$ & $\begin{array}{l}\text { Nyaris tidak efektif. } \\
\text { Anggota tidak terlibat } \\
\text { sepenuh hati }\end{array}$ \\
\hline Institusi Keagamaan & $\bullet$ Kecil & - Sulit mencari tokoh \\
& & $\begin{array}{l}\text { agama yang dihormati } \\
\text { oleh kedua belah pihak. }\end{array}$ \\
& & $\begin{array}{l}\text { Figur ulama tidak turun } \\
\text { langsung ketika konflik } \\
\text { berlangsung untuk } \\
\text { mengamankan situasi. }\end{array}$ \\
\hline
\end{tabular}

Sumber: Heru Cahyono, 2008.

Tabel di atas yang menunjukkan bahwa peran serta pemerintah pusat maupun daerah kurang berhasil. Peran ulama dan dinasti habib yang tentunya memiliki fungsi besar ternyata belum mampu meredam pertikaian di Sambas.

\section{SIMPULAN}

Terjadinya konflik antar etnis di Sambas tidak bisa dilepaskan dari masalahmasalah sebelumnya. Orang Melayu Sambas sebagian besar bekerja pada sektor agraris dan nelayan yang penghasilannya cukup untuk kebutuhan sehari-hari. Pada 1992 di Sambas mulai dikembangkannya tanaman jeruk sehingga petani membuka lahannya dengan tanaman jeruk. Pada waktu itu memang taraf hidup petani naik karena. Dengan dimonopolinya pasaran jeruk oleh perusahaan ternyata menjadi masalah baru yang berujung pada hancurnya harga jeruk.

Pendatang yang memiliki akses dan kemudahan serta berhasil dalam berbagai sektor sebagai pemain baru menggantikan peran orang Melayu Sambas. Kendati demikian masyarakat Sambas yang berprofesi sebagai petani dapat hidup karena masih terbantu oleh pekerjaan pada tanaman padi, kelapa, kakao, karet dan nelayan. Secara struktural orang Madura banyak yang memiliki lahan, pertambangan dan bahkan ada yang duduk di kursi parlemen. Hal ini tampak menjadi permasalan yang sangat komplek, dan tidak mau membaurnya orang-orang Madura merupakan alasan yang konkret terjadinya konflik etnis di Sambas. Konflik etnis Sambas pada 1999 adalah akibat dari tidak berfungsinya peran pemerintah pusat dan daerah serta tokoh-tokoh terkemuka di Sambas.

\section{DAFTAR PUSTAKA}

Arief, Oesman, 2011. Multikultural. Mewujudkan Tatanan Masyarakat Multicultural: Sebuah Tantangan di Era Glogal. Makalah Seminar Nasional 16 Pebruari 2011. Surakarta. UNS.

BPS Kabupaten Sambas 1999.

Cahyono, Heru dkk. 2008. Konflik Kalbar dan Kalteng: Tantangan Perdamaian dan Reintegrasi. Yogyakarta: Pustaka Pelajar dan P2P-LIPI.

Haryono, Dwi dan Budi Winarno. 2003. The Struktur Faktors Cousing the Conflict between the Malay and the Madura Etnics at Sambas District of West Kalimantan. Sosiohumanika Jurnal Gajah Mada.

Kompas edisi Rabu 20 Desember 2000 yang ditulis oleh Jannes Eudes Wawa 
dengan judul Konflik Orang-orang Di Kalbar.

Liliweri, Ale, A.S. 2005. Prasangka dan Konflik: Komunikasi Lintas Budaya Masyarakat Multikultur. Yogyakarta: LKIS

Mahfud, Cairul. 2009. Pendidikan Multikultur. Yogyakarta: Pustaka Pelajar.

Mandayun, Rustam F dan Iwan Setiawan, 1999. Mereka Lari ke Malaysia www.library.ohiou.edu/indopubs/1999 104/01/0094.
Purwana, Bambang Hendrarta Suta. 2003. Konflik Antar komunitas di Sambas 1999; Suatu Tinjauan Budaya. Pontianak: Romeo Grafika.

Rothhschild, Josep, 1981. Etnopolitics, A Conceptual Frame Work. Colombia University Press, Ny.

Sudagung, Hendro Suroyo. 2001. Mengurai Pertikaian Orang-orang: Migrasi Swakarsa Orang-orang Mabura ke Kalimantan Barat. Jakarta: ISAI. 